Jurnal Ekonomi Pembangunan, 16 (1), Juni 2015, 33-45

\title{
Strategy for Strengthening Farmer Groups by Institutional Strengthening
}

\author{
Purbayu Budi Santoso, Darwanto \\ Faculty of Economics and Business, Universitas Diponegoro \\ Jalan Prof. Soedharto, SH. Tembalang, Semarang, Jawa Tengah, Indonesia \\ Telp: +62-024-76486851,E-mail: purifada@yahoo.com
}

Received: January 2015; Accepted: May 2015

\begin{abstract}
Agriculture sector becomes a spotlight because this sector will be full of potential but the welfare of farmers who become the leading actor is not guaranteed and has a poor tendency. The purpose of this study is to formulate strategies to strengthen farmers' groups in order to create the marketing of the agricultural sector that benefit farmers. The method used to achieve this goal is to use a qualitative approach and Analytical Network Process. In addition to the secondary data obtained from several agencies, this study also uses primary data obtained by in-depth interviews and observations. This research results a priority of aspects of the institutional strengthening of farmer groups as well as priority issues and priorities of the solution of each aspect. In addition, the priority of alternative strategies resulted based on the problems and solutions that have been analyzed in order to solve the problems in the institutional strengthening of farmer groups in Demak.
\end{abstract}

Keywords: institutional, farmer groups, trade system, ANP

JEL Classification: Q130, Q18, O13

\section{Strategi Penguatan Kelompok Tani dengan Penguatan Kelembagaan}

\begin{abstract}
Abstrak
Sektor pertanian menjadi salah satu sektor yang menjadi sorotan karena sektor ini sarat akan potensi akan tetapi kesejahteraan petani yang menjadi pelaku utamanya justru tidak terjamin dan memiliki kecenderungan miskin. Tujuan penelitian ini adalah merumuskan strategi penguatan kelompok tani guna menciptakan tata niaga sektor pertanian yang menguntungkan petani. Metode yang digunakan untuk mencapai tujuan tersebut adalah dengan menggunakan pendekatan kualitatif dan analytical network process. Selain data sekunder yang diperoleh dari beberapa instansi, penelitian ini juga menggunakan data primer yang diperoleh dengan in-depth interview dan observasi. Penelitian ini menghasilkan prioritas dari aspek dalam penguatan kelembagaan kelompok tani dan juga prioritas permasalahan serta prioritas solusi dari masing-masing aspek. Selain itu juga, prioritas strategi alternatif yang dihasilkan berdasarkan permasalahan dan solusi yang telah dianalisis guna menyelesaikan permasalahan dalam penguatan kelembagaan kelompok tani di Kabupaten Demak.
\end{abstract}

Kata kunci: kelembagaan, kelompok tani, tata niaga, ANP.

Klasifikasi JEL: Q130, Q18, O13

\section{Pendahuluan}

Pembangunan pertanian di Indonesia dan negara berkembang lainnya tidak sesederhana yang diduga. Permasalahan yang paling krusial adalah pasar dan politik sama-sama mengesampingkan sektor pertanian dan sektor lain dengan basis sumberdaya alam (Arifin, 2004). Padahal sektor pertanian masih merupakan 


\section{Jurnal Ekonomi Pembangunan, 16 (1), Juni 2015, 33-45}

sektor strategis yang menjadi basis ekonomi masyarakat perdesaan dan sangat berperan terhadap penyerapan tenaga kerja. Selain itu, sektor pertanian juga menjadi katup pengaman ketika perekonomian mengalami krisis dimana sektor lain tidak cukup kuat menghadapi guncangan ekonomi tersebut.

Selain masalah kebijakan pembangunan yang mengesampingkan sektor pertanian, permasalahan lain yang dihadapi oleh sektor pertanian adalah masalah kelembagaan dan tata niaga. Kelembagaan petani diperlukan untuk mengelola faktor-faktor produksi, proses produksi, sampai dengan pengolahan hasil pertanian. Pentingnya kelembagaan petani diakui dalam pembangunan pertanian, baik di negara industri maupun negara sedang berkembang seperti Indonesia. Kelembagaan dalam usaha tani mempunyai peran yang cukup penting dalam hampir setiap tahapan usaha tani. Namun, mayoritas kelompok masih dalam tingkatan pemula sehingga kinerja yang rendah (Wahyuni, 2003). Namun kenyataan memperlihatkan kecenderungan masih lemahnya kelembagaan petani di negara berkembang, serta besarnya hambatan dalam menumbuhkan kelembagaan pada masyarakat petani (Anantanyu, 2008). Padahal kelembagaan petani diharapkan mampu membantu petani keluar dari persoalan kesenjangan ekonomi petani, namun sampai saat ini masih belum berfungsi secara optimal.

Di tingkat makro nasional, peran kelembagaan pertanian sangat menonjol dalam program dan proyek intensifikasi dan peningkatan produksi pangan. Kelembagaan tersebut terkesan dipaksakan sehingga seringkali tidak berjalan optimal. Kegiatan pembangunan pertanian yang dituangkan dalam bentuk program dan proyek dengan membangun kelembagaan koersif (kelembagaan yang dipaksakan) tersebut antara lain Padi Sentra, Demonstrasi Massal (Demas), Bimbingan Massal (Bimas), Bimas Gotong Royong, Badan Usaha Unit Desa (BUUD), Koperasi Unit Desa (KUD), Insus, dan Supra Insus. Pada subsektor peternakan dikembangkan berbagai program dan lembaga pembangunan koersif, seperti Bimas Ayam Ras, Intensifikasi Ayam Buras (Intab), Intensifikasi
Ternak Kerbau (Intek), dan berbagai program serta kelembagaan intensifikasi lainnya (Nasrul, 2012). Kondisi di atas menunjukkan bahwa pemerintah menyadari bahwa keberdayaan kelembagaan dalam akselerasi pembangunan sektor pertanian adalah diperlukan.

Dampak dari kelembagaan petani yang lemah dan belum optimal adalah rendahnya posisi tawar petani dalam tata niaga produk pertanian. Ini terlihat dari rendahnya harga yang diterima petani atas produk yang dihasilkan, walaupun harga produk pertanian yang dibayar konsumen di waktu yang bersa-maan cukup tinggi. Padahal resiko akan kegagalan panen yang dihadapi petani juga tinggi. Hal ini disebabkan oleh dominannya peran pedagang besar dan tengkulak dalam menentukan harga melalui kekuatan modal yang dimiliki. Struktur pembagian margin pemasaran yang tidak merata dan tidak sesuai dengan resiko usaha tersebut menunjukkan lemahnya posisi tawar petani terhadap pelaku tata niaga selanjutnya. Sekaligus hal ini juga mengindikasikan adanya kecenderungan praktek oligopsoni dan sistem tata niaga yang belum efisien.

Tiga komponen utama yang mendukung tata niaga pertanian adalah produsen, pedagang, dan konsumen. Petani sebagai produsen perlu didukung oleh paket teknologi dan lembaga penyedia sarana produksi yang mampu menyediakan secara lima tepat (tepat waktu, jenis, ukuran, tempat, dan harga). Anjuran paket teknologi pertanian sesungguhnya telah disadari manfaatnya oleh petani, yaitu untuk meningkatkan produksi, namun belum sepenuhnya diterapkan karena terbentur masalah pendanaan. Konsekuensinya, produksi belum optimal, baik jumlah maupun mutu, sehingga akan mempersulit pemasaran hasil, terutama untuk tujuan ekspor. Hal lain yang dihadapi petani dalam pemasaran produksi adalah belum dapat menjual langsung kepada pedagang besar (eksportir), PUSKUD, atau pedagang lainnya di kota provinsi. Petani umumnya menjual hasil jagung hanya ke pedagang pengumpul atau ke pasar (pedagang penyalur kota atau pengecer di pasar umum).

Kelompok-kelompok tani di pedesaaan terbentuk karena adanya ikatan yang didasar- 


\section{Jurnal Ekonomi Pembangunan, 16 (1), Juni 2015, 33-45}

kan pada kesamaan usaha, mempunyai tujuan mengelola usaha taninya atas dasar kebersamaan dan pemenuhan sarana usaha. Pembentukan kelompok ini mampu mendorong tumbuhnya kepekaan, kreativitas, inovasi, motivasi, solidaritas dan rasa tanggungjawab serta partisipasi anggota (Hasan, 2009). Akan tetapi, pengembangan kelompok tani ini bukan merupakan pekerjaan mudah mengingat beberapa kendala yang dihadapi seperti berikut (Dimyati dalam Nasrul, 2012):

1) Masih minimnya wawasan dan pengetahuan petani terhadap masalah manajemen produksi maupun jaringan pemasaran. 2) Belum terlibatnya secara utuh petani dalam kegiatan agribisnis. Aktivitas petani masih terfokus pada kegiatan produksi (on farm). 3) Peran dan fungsi kelembagaan petani sebagai wadah organisasi petani belum berjalan secara optimal.

Kelembagaan petani di daerah pedesaan, umumnya tidak berjalan dengan baik disebabkan oleh beberapa faktor, yaitu: (1) kelompok tani pada umumnya dibentuk berdasarkan kepentingan teknis untuk memudahkan pengoordinasian apabila ada kegiatan atau program pemerintah, sehingga lebih bersifat orientasi program, dan kurang menjamin kemandirian kelompok dan keberlanjutan kelompok, (2) partisipasi dan kekompakan anggota kelompok dalam kegiatan kelompok relatif rendah ini tercermin dari tingkat kehadiran anggota dalam pertemuan kelompok rendah, (3) pengelolaan kegiatan produktif anggota kelompok bersifat inividu. Kelompok sebagai forum kegiatan bersama belum mampu menjadi wadah pemersatu kegiatan anggota dan pengikat kebutuhan anggota secara bersama, sehingga kegiatan produktif individu lebih menonjol, (4) pembentukan dan pengembangan kelembagaan tidak menggunakan basis social capital setempat dengan prinsip keotonomian dan pemberdayaan, (5) pembentukan dan pengembangan kelembagaan berdasarkan konsep cetak biru (blue print approach) yang seragam. Introduksi kelembagaan dari luar kurang memperhatikan struktur dan jaringan kelembagaan lokal yang telah ada, serta kekhasan ekonomi,sosial, dan politik yang berjalan, (6) pembentukan dan pengembangan kelembagaan berdasarkan pen- dekatan yang top down, menyebabkan tidak tumbuhnya partisipasi masyarakat, (7) kelembagaan-kelembagaan yang dibangun terbatas hanya untuk memperkuat ikatan horizontal, bukan ikatan vertikal, dan (8) pengembangan kelembagaan selalu menggunakan jalur struktural, dan lemah dari pengembangan aspek kulturalnya (Parma, 2014).

Untuk mengatasi permasalahan di atas perlu melakukan upaya pengembangan, pemberdayaan, dan penguatan kelompok tani untuk menciptakan kelembagaan dan tata niaga sektor pertanian yang menguntungkan petani. Hal ini diharapkan dapat melindungi bargaining position petani dan meningkatkan kesejahteraannya. Indikator penguatan kelompok tani dapat diwujudkan melalui tingkat harga output yang layak dan menguntungkan petani. Dengan demikian, penguatan dan pemberdayaan kelompok tani tersebut juga diharapkan menghasilkan pencapaian kesinambungan dan keberlanjutan daya dukung sumber daya alam dan berbagai usaha untuk menopang dan menunjang aktivitas kehidupan pembangunan pertanian.

Konsep Strategi dan Daya Saing. Strategi adalah tujuan jangka panjang dari suatu organisasi/ perusahaan, serta pendayagunaan dan alokasi semua sumber dana yang penting untuk mencapai tujuan tersebut (Rangkuti, 2006). Pemahaman yang baik mengenai konsep strategi dan konsep-konsep lain yang berkaitan, sangat menentukan suksesnya strategi yang disusun. Konsep-konsep yang menentukan suksesnya strategi yang disusun adalah sebagai berikut (Rangkuti, 2006):

Distinctive Competence; yaitu tindakan yang dilakukan untuk perusahaan agar dapat melakukan kegiatan lebih baik dibandingkan dengan pesaingnya. Dua faktor yang biasa diidentifikasi adalah keahlian tenaga kerja dan kemampuan sumber dayanya.

Competitive Advantage; yaitu kegiatan spesifik yang dikembangkan oleh perusahaan agar lebih unggul dibandingkan dengan pesaingnya. Biasanya yang dilakukan oleh perusahaan dengan memberikan perhatian lebih pada 3 (tiga) faktor yaitu; cost leadership, diferensial dan fokus. 


\section{Jurnal Ekonomi Pembangunan, 16 (1), Juni 2015, 33-45}

Adapun tipe-tipe strategi menurut Rangkuti (2006) dapat dibagi tiga yaitu strategi manajemen, strategi investasi, dan strategi bisnis. Penjelasan dari masing-masing strategi tersebut adalah sebagai berikut:

a) Strategi manajemen yaitu strategi yang dapat dilakukan oleh manajemen dengan orientasi pengembangan strategi secara makro misalnya, strategi pengembangan produk, strategi penerapan harga, strategi akusisi, strategi pengembangan pasar, strategi mengenai keuangan dan sebagainya.

b) Strategi investasi, strategi ini merupakan kegiatan yang berorientasi pada investasi. Misalnya apakah perusahaan ingin melakukan strategi pertumbuhan yang agresif atau berusaha mengadakan penetrasi pasar, strategi bertahan, strategi pembangunan kembali suatu divisibaru atau strategi divestasi dan sebagainya.

c) Strategi Bisnis yaitu biasa disebut juga dengan strategi bisnis secara fungsional karena strategi berorientasi pada fungsi-fungsi kegiatan manajemen, misalnya strategi pemasaran, strategi produksi atau operasional, strategi distribusi, strategi organisasi dan strategistrategi yang berhubungan dengan keuangan.

Konsep strategi juga diperlukan untuk melakukan aktivitas pemberdayaan baik pemberdayaan individu masyarakat maupun kelompok masyarakat. Pemberdayaan sendiri dapat dimaknai sebagai proses untuk memperoleh daya, kekuatan atau kemampuan, dan atau proses pemberian daya, kekuatan atau kemampuan dari pihak yang memiliki daya kepada pihak yang kurang atau belum berdaya (Sulistiyani, 2004). Kartasasmita (1996) menyampaikan bahwa proses pemberdayaan dapat dilakukan melalui tiga proses yaitu:

a) menciptakan suasana atau iklim yang memungkinkan potensi masyarakat berkembang (enabling). b) memperkuat potensi atau daya yang dimiliki oleh masyarakat (empowering), c) memberdayakan juga mengandung arti melindungi. Adapun salah satu tujuan yang ingin dicapai dari pemberdayaan kelompok tani adalah untuk membantu kelompok tani menjadi mandiri.
Kelembagaan Kelompok Tani dan Tata Niaga. Salah satu permasalahan dalam pengelolaan sumberdaya pertanian adalah masalah kelembagaan pertanian yang tidak mendukung, salah satunya kelembagaan petani. Untuk itu perlu adanya pembangunan kelembagaan petani yang dilandasi pemikiran bahwa: (a) Proses pertanian memerlukan sumberdaya manusia tangguh yang didukung infrastruktur, peralatan, kredit, dan sebagainya; (b) Pembangunan kelembagaan petani lebih rumit daripada manajemen sumberdaya alam karena memerlukan faktor pendukung dan unit-unit produksi; (c) Kegiatan pertanian mencakup tiga rangkaian: penyiapan input, mengubah input menjadi produk dengan usaha tenaga kerja dan manajemen, dan menempatkan output menjadi berharga; (d) Kegiatan pertanian memerlukan dukungan dalam bentuk kebijakan dan kelembagaan dari pusat hingga lokal; dan (e) Kompleksitas pertanian, yang meliputi unit-unit usaha dan kelembagaan, sulit mencapai kondisi optimal. (Anantanyu, 2011)

Kelembagaan adalah suatu aturan yang dikenal, diikuti dan ditegakkan secara baik oleh anggota masyarakat, yang memberi naungan dan hambatan bagi individu atau anggota masyarakat (Arifin, 2004). Kelembagaan dalam pertanian diperlukan untuk melindungi petani dan menjaga keteraturan aktivitas petani baik dalam kegiatan produksi maupun usaha tani lainnya. Menurut Bromley (1989) dalam Arifin (2004) mengemukakan bahwa kelembagaan adalah serangkaian hubungan keteraturan antara beberapa orang yang menentukan hak, kewajiban atau tepatnya kewajiban menghargai hak orang lain, privilis dan tanggung jawab dalam masyarakat atau kelembagaan tersebut.

Kelompok tani sebagai bagian integral pembangunan pertanian memiliki peran dan fungsi penting dalam menggerakkan pembangunan pertanian di perdesaan. Kelompok tani pada dasarnya sebagai pelaku utama dalam pembangunan pertanian di perdesaan. Dalam hal ini keberadaan kelompok tani dapat memainkan peran tunggal atau ganda, seperti penyediaan input usaha tani (misalnya pupuk), penyediaan modal (misalnya simpan pinjam), 


\section{Jurnal Ekonomi Pembangunan, 16 (1), Juni 2015, 33-45}

penyediaan air irigasi (kerjasama dengan P3A), penyedia informasi (penyuluhan melalui kelompok tani), serta pemasaran hasil secara kolektif. (Hermanto dkk, 2011). Peran kelembagaan petani dalam mendukung keberlanjutan pertanian sangat diperlukan untuk memberikan masukan dan pertimbangan bagi pelaku pembangunan dalam rangka pengembangan ekonomi lokal (Cahyono dkk, 2013).

Kelompok tani bisa dikategorikan sebagai wujud kelembagaan ekonomi untuk memenuhi kebutuhan petani. Darmajanti dalam Hasan (2009) menjelaskan bahwa kelompok sebagai gambaran kehidupan berorganisasi suatu komunitas merupakan refleksi dinamika tindakan kolektif warga dalam mengatasi masalah bersama, termasuk peningkatan pendapatan rumah tangga di komunitas. Dalam aktivitasnya, kelompok tani mencerminkan bentuk komunitas yang di dalamnya terdapat dinamika tindakan kolektif untuk mencapai tujuan bersama. Kegiatan kolektif tersebut terlihat dari kegiatan produksi, distribusi, dan pengolahan hasil. Walaupun aspek distribusi dan pengolahan hasil biasanya dilakukan oleh pihak lain, namun untuk memperkuat posisi tawar petani di dalam mengembangkan kemandiriannya maka kedua aspek tersebut selayaknya dikelola melalui kelompok.

Kemandirian dan keberdayaan petani dapat dilihat juga pada posisi tawar petani dalam tata niaga produk pertanian. Akhmad dalam Nasrul (2012) menyebutkan upaya yang harus dilakukan petani untuk menaikkan posisi tawar petani adalah dengan:

a) Konsolidasi petani dalam satu wadah untuk menyatukan gerak ekonomi dalam setiap rantai pertanian, dari pra produksi sampai pemasaran. Konsolidasi tersebut pertama dilakukan dengan kolektifikasi semua proses dalam rantai pertanian, meliputi kolektifikasi modal, kolektifikasi produksi, dan kolektifikasi pemasaran. Kolektifikasi modal adalah upaya membangun modal secara kolektif dan swadaya, misalnya dengan gerakan simpan-pinjam produktif yang mewajibkan anggotanya menyimpan tabungan dan meminjamnya sebagai modal produksi, bukan kebutuhan konsumtif. Hal ini dilakukan agar pemenuhan modal kerja pada awal masa tanam dapat dipenuhi sendiri, dan mengurangi ketergantungan kredit serta jeratan hutang tengkulak.

b) Kolektifikasi produksi, yaitu perencanaan produksi secara kolektif untuk menentukan pola, jenis, kuantitas dan siklus produksi secara kolektif. Hal ini perlu dilakukan agar dapat dicapai efisiensi produksi dengan skala produksi yang besar dari banyak produsen. Efisisensi dapat dicapai karena dengan skala yang lebih besar dan terkoordinasi dapat dilakukan penghematan biaya dalam pemenuhan faktor produksi, dan kemudahan dalam pengelolaan produksi, misalnya dalam penanganan hama dan penyakit. Langkah ini juga dapat menghindari kompetisi yang tidak sehat di antara produsen yang justru akan merugikan, misalnya dalam irigasi dan jadwal tanam.

c) Kolektifikasi dalam pemasaran produk pertanian. Hal ini dilakukan untuk mencapai efisiensi biaya pemasaran dengan skala kuantitas yang besar, dan menaikkan posisi tawar produsen dalam perdagangan produk pertanian. Kolektifikasi pemasaran dilakukan untuk mengkikis jaring-jaring tengkulak yang dalam menekan posisi tawar petani dalam penentuan harga secara individual. Upaya kolektifikasi tersebut tidak berarti menghapus peran dan posisi pedagang distributor dalam rantai pemasaran, namun tujuan utamanya adalah merubah pola relasi yang merugikan petani produsen dan membuat pola distribusi lebih efisien dengan pemangkasan rantai tata niaga yang tidak menguntungkan.

Proses pengambilan keputusan dalam masyarakat petani merupakan tindakan berbasis komunitas (community-based action) yang dapat dimanfaatkan sebagai salah satu celah masuk upaya diseminasi teknologi. Dengan demikian setiap upaya pemberdayaan kelembagaan petani memiliki keterkaitan kuat dengan kondisi tekno-sosial komunitas petani. Keberhasilan suatu program pemberdayaan merupakan resultan interaksi elemen-elemen pemberdayaan dengan strategi pemberdayaan yang diterapkan. Upaya dan strategi pemberdayaan merupakan suatu pendulum antara paradigma 
evolusi dan paradigma revolusi yang saling mengisi dalam proporsi yang sesuai dengan kondisi dan kebutuhan kelembagaan petani (Suradisastra, 2008).

\section{Metode Penelitian}

\subsection{Lokasi Penelitian}

Penelitian ini dilakukan di Provinsi Jawa Tengah, di mana Jawa Tengah masih memiliki lahan pertanian yang luas dan sebagian besar penduduknya bekerja di sektor pertanian. Secara khusus penelitian ini dilakukan pada daerah Pantura Jawa Tengah yang masih memiliki pertanian padi cukup besar yaitu Kabupaten Demak.

\subsection{Metode Pengumpulan Data}

Metode pengumpulan data sekunder yang digunakan dalam penelitian ini adalah metode dokumentasi. Metode dokumentasi dilakukan dengan cara mengumpulkan data dari berbagai literatur dan juga data yang berasal dari publikasi Badan Pusat Statistik, Badan Perencanaan dan Pembangunan Daerah, Dinas Pertanian, dan instansi yang terkait lainnya. Adapun metode pengumpulan data primer pada penelitian ini dilakukan dengan berbagai cara melalui:

1) Wawancara Mendalam (Indepth Interview), dilakukan untuk mendapatkan informasi yang mendalam tentang kondisi kelompok tani.

2) Observasi langsung, dilakukan dengan meninjau secara langsung dan melakukan interaksi dengan petani-petani dan kelompok tani. Hal ini dilakukan untuk mencari informasi tambahan dan untuk mengetahui kondisi yang sebenarnya yang meliputi permasalahan, kendala dan hal-hal yang dibutuhkan oleh kelompok tani.

\subsection{Teknik Analisis Data}

Data yang diperoleh dari penelitian akan dianalisis dengan metode Analytical Network Process (ANP) yang merupakan metode yang dapat digunakan dalam berbagai studi kualitatif yang beragam, seperti pengambilan keputusan, fore- casting, evaluasi, mapping, strategizing, alokasi sumber daya, dan lain sebagainya (Saaty, 1993).

\subsection{Tahapan Penelitian ANP}

a) Konstruksi Model. Konstruksi model ANP disusun berdasarkan literature review secara teori maupun empiris dan memberikan pertanyaan pada pakar dan praktisi yang berkaitan dengan kelompok tani serta melalui indepth interview atau focus Group Discussion (FGD) untuk mengkaji informasi secara lebih dalam untuk memperoleh permasalahan yang sebenarnya.

b) Kuantifikasi Model. Tahap kuantifikasi model menggunakan pertanyaan dalam kuesioner ANP berupa pairwise comparison (pembandingan pasangan) antarelemen dalam cluster untuk mengetahui mana di antara keduanya yang lebih besar pengaruhnya (lebih dominan) dan seberapa besar perbedaannya melalui skala numerik 1-9.

\section{c) Sintesis dan Analisis}

Geometric Mean. Untuk mengetahui hasil penilaian individu dari para responden dan menentukan hasil pendapat pada satu kelompok dilakukan penilaian dengan menghitung geometric mean. Pertanyaan berupa perbandingan (Pairwise comparison) dari responden akan dikombinasikan sehingga membentuk suatu konsensus. Geometric mean merupakan jenis penghitungan rata-rata yang menunjukan tendensi atau nilai tertentu

Rater Agreement. Rater agreement adalah ukuran yang menunjukan tingkat kesesuaian (persetujuan) para responden (R1-Rn) terhadap suatu masalah dalam satu cluster. Adapun alat yang digunakan untuk mengukur rater agreement adalah Kendall's Coefficient of Concordance $(\mathrm{W} ; 0<\mathrm{W} \leq 1)$. $\mathrm{W}=1$ menunjukkan kesesuaian yang sempurna. Untuk menghitung Kendall's $(W)$, yang pertama adalah dengan memberikan rangking pada setiap jawaban kemudian menjumlahkannya (Ascarya, 2010).

\section{Hasil dan Pembahasan}

\subsection{Dekomposisi}

\subsubsection{Identifikasi Aspek}


Ada beberapa permasalahan dalam pemberdayaan kelompok tani dalam menciptakan tata niaga dan kelembagaan yang menguntungkan petani di Kabupaten Demak, antara lain dikelompokkan menjadi 5 aspek yaitu aspek kelembagaan, aspek tata niaga, aspek teknologi, aspek infrastruktur dan aspek kemitraan.

a) Aspek Kelembagaan: Aspek yang berkaitan dengan Organisasi, peran dan fungsinya, norma yang ada di dalamnya, serta kontribusi dari petani terhadap kelompok tani

b) Aspek Tata Niaga: Aspek yang berkaitan dengan semua proses dalam produksi yang meliputi input, produksi, output dan distribusinya

c) Aspek Teknologi: Aspek yang terkait dengan jenis teknologi yang digunakan dan yang dibutuhkan oleh kelompok tani

d) Aspek Infrastruktur: Aspek yang berkaitan dengan jenis dan jumlah sarana serta prasarana yang dibutuhkan oleh kelompok tani

e) Aspek Kemitraan: Aspek yang berkaitan dengan kerjasama dengan pihak-pihak yang terkait (Stakeholders) dengan kelompok Tani

Aspek-aspek yang telah teridentifikasi, kemudian dibagi dalam cluster-cluster yaitu cluster permasalahan, solusi dan strategi. Masing-masing cluster terdiri dari sub-sub cluster yang kemudian dibandingkan untuk memperoleh prioritas dari masing-masing cluster maupun sub-cluster.

\subsubsection{Identifikasi Masalah}

\section{1) Cluster Permasalahan kelembagaan}

Cluster ini terbagi menjadi 4 sub-cluster yaitu sub-cluster organisasi; fungsi dan peran; norma; serta inovasi dan kontribusi.

a) Organisasi: Kurang optimalnya kinerja dari pengurus dan anggota organisasi kelompok tani yang akan berpengaruh pada kondisi dari kelompok tani serta segala macam kegiatan yang dilakukan oleh petani.

b) Fungsi dan Peran: Fungsi dan peran organisasi yang masih kurang bagi anggota kelompok tani yang dirasa masih kurang optimal bagi para anggotanya atau petani.

c) Norma: Penerapan norma tertulis yang pelaksanaannya tidak sesuai dengan AD/ART dan memiliki kecenderungan melanggar dari apa yang menjadi kesepakatan bersama dari para petani.

d) Inovasi dan Kontribusi: kurangnya inovasi dan kontribusi/masukan yang membangun bagi penerap dini (kesadaran, minat, menilai, mencoba dan menerapkan). Inovasi dan kontribusi dari para petani dalam membagun pertanian masih kurang dan cenderung menerima anjuran dari pemerintah atau sesuai dengan tradisi yang sudah ada.

\section{2) Cluster Permasalahan tata niaga}

Cluster ini terbagi menjadi 3 sub-cluster yaitu sub-cluster input, produksi dan pasca panen.

a) Input: Masalah permodal kelompok tani yang kecil sehingga tidak memenuhi sarana dan prasarana produksi.

b) Produksi: Masalah pengadaan pupuk bersubsidi dan obat pembasmi hama (harga, sortasi, gradding dan brand).

c) Pascapanen: Tidak ada perlakuan untuk produk yang dihasilkan (hanya mempertahankan mutu dan perkembangan hasil) dan daerah distribusi yang masih terbatas.

\section{3) Cluster permasalahan Teknologi}

Cluster ini terbagi menjadi 3 sub-cluster yaitu sub-cluster standar mutu, jenis teknologi serta kegunaan dan kebutuhan teknologi.

a) Standar Mutu: Sapta usaha produksi yag digunakan kurang optimal dalam penerapan teknologi

b) Jenis Teknologi: Jenis teknologi yang digunakan terbatas dan jumlahnya tidak banyak (masih tahap adopsi dan sadar teknologi)

c) Kegunaan dan Kebutuhan: Ketidaksesuaian teknologi yang diberikan melalui bantuan dengan yang dibutuhkan oleh petani

\section{4) Cluster permasalahan infrastruktur}

Cluster ini terbagi menjadi 3 sub-cluster yaitu sub-cluster kondisi sarana prasarana, kuantitas dan kebutuhan.

a) Kondisi Sarana Prasarana: Masih banyak sarana dan prasarana yang rusak serta tidak layak.

b) Kuantitas: Jumlah sarana dan prasarana yang masih kurang memadai guna memperlancar usaha tani. 
Jurnal Ekonomi Pembangunan, 16 (1), Juni 2015, 33-45

c) Kebutuhan: Masih banyak kebutuhan sarana dan prasaran yang dibutuhkan oleh petani.

\section{5) Cluster Permasalahan Kemitraan}

Cluster ini terbagi menjadi 3 sub-cluster yaitu sub-cluster sistem kemitraan, koordinasi stakeholders, dan jenis kemitraan.

a) Sistem Kemitraan: Sistem kemitraan yang sering tidak menguntungkan pihak petani karena tidak ada MoU (perjanjian tertulisnya).

b) Koordinasi Stakeholders: Koordinasi dilapangan yang masih kurang karena jarang ada pemantauan dari pihak yang terkait dengan petani atau kelompok tani.

c) Jenis Kemitraan: Jenis kemitraan yang masih terbatas jumlahnya.

\subsubsection{Identifikasi Solusi}

Adapun alternatif solusi yang dapat dilakukan dalam penguatan kelembagaan kelompok tani di Kabupaten Demak yaitu antara lain:

1) Solusi Kelembagaan

a) Optimalisasi Kinerja Organisasi Kelompok Tani dengan pertemuan rutin kelompok.

b) Optimalisasi Fungsi dan Peran Kelompok Tani sesuai AD/ART.

c) Memperjelas dan menerapkan norma yang berlaku di Kelompok Tani.

d) Memperbanyak inovasi dan Kontribusi Petani terhadap Kelompok Tani.

2) Solusi Tata Niaga

a) Manajemen pengadaan input agar tepat waktu dan tersedia sebelum masa tanam mulai.

b) Optimalisasi hasil produksi melalui pemberian pupuk bersubsidi dan obat pembasmi hama.

c) Perlakuan terhadap hasil produksi untuk memberikan nilai tambah dan strategi pemasaran sesuai dengan keinginan konsumen.

3) Solusi Teknologi

a) Meningkatkan teknologi yang digunakan guna meningkatkan mutu produk yang dihasilkan.

b) Menambah jumlah dan jenis sarana serta prasarana seperti traktor dan mesin perontok padi (menerapkan teknologi sesuai anjuran/ sapta usaha tani). c) Optimalisasi teknologi sesuai dengan kegunaan dan kebutuhan petani.

4) Solusi Infrastruktur

a) Perbaikan sarana dan prasarana yang rusak dan kurang layak.

b) Penambahan jumlah dan jenis sarana dan prasarana.

c) Pengadaan infrastruktur yang sesuai dengan yang dibutuhkan oleh petani.

5) Solusi Kemitraan

a) Perbaikan dan merubah sistem kemitraan yang kurang menguntungkan bagi kelompok tani dengan membuat MoU (perjanjian tertulis).

b) Meningkatkan kerjasama antar Stakeholders yang terkait dengan petani.

c) Memantapkan kemitraan yang ada yang meliputi seperti pasar, teknologi dan modal.

\subsubsection{Identifikasi Strategi}

Identifikasi masalah dan solusi yang dilakukan dalam studi ini menghasilkan strategi dalam penguatan kelembagaan kelompok tani yaitu:

1) Optimalisasi fungsi dan peran organisasi melalui inovasi dan kontribusi petani terhadap kelompok tani

2) Manajemen dan Optimalisasi proses produksi agribisnis dari hulu sampai hilir serta pengelolaan/manajemen usaha tani yang lebih profesional

3) Penerapan teknologi yang tepat guna sebagai langkah untuk menambah nilai tambah produk yang dihasilkan

4) Manajemen infrastruktur melalui perbaikan dan penambahan sesuai dengan yang dibutuhkan oleh petani

5) Meningkatkan Koordinasi dengan Stakeholders yang terkait dengan petani dan menjalin hubungan baik dengan mitra petani

\subsection{Jaringan ANP}

Hasil identifikasi masalah dan solusi tersebut, selanjutnya dibuat jaringan struktur ANP dalam penguatan kelembagaan kelompok tani di Kabupaten Demak, tampak dalam Gambar 1. 
Avalaible online at http://journals.ums.ac.id

Jurnal Ekonomi Pembangunan, 16 (1), Juni 2015, 33-45

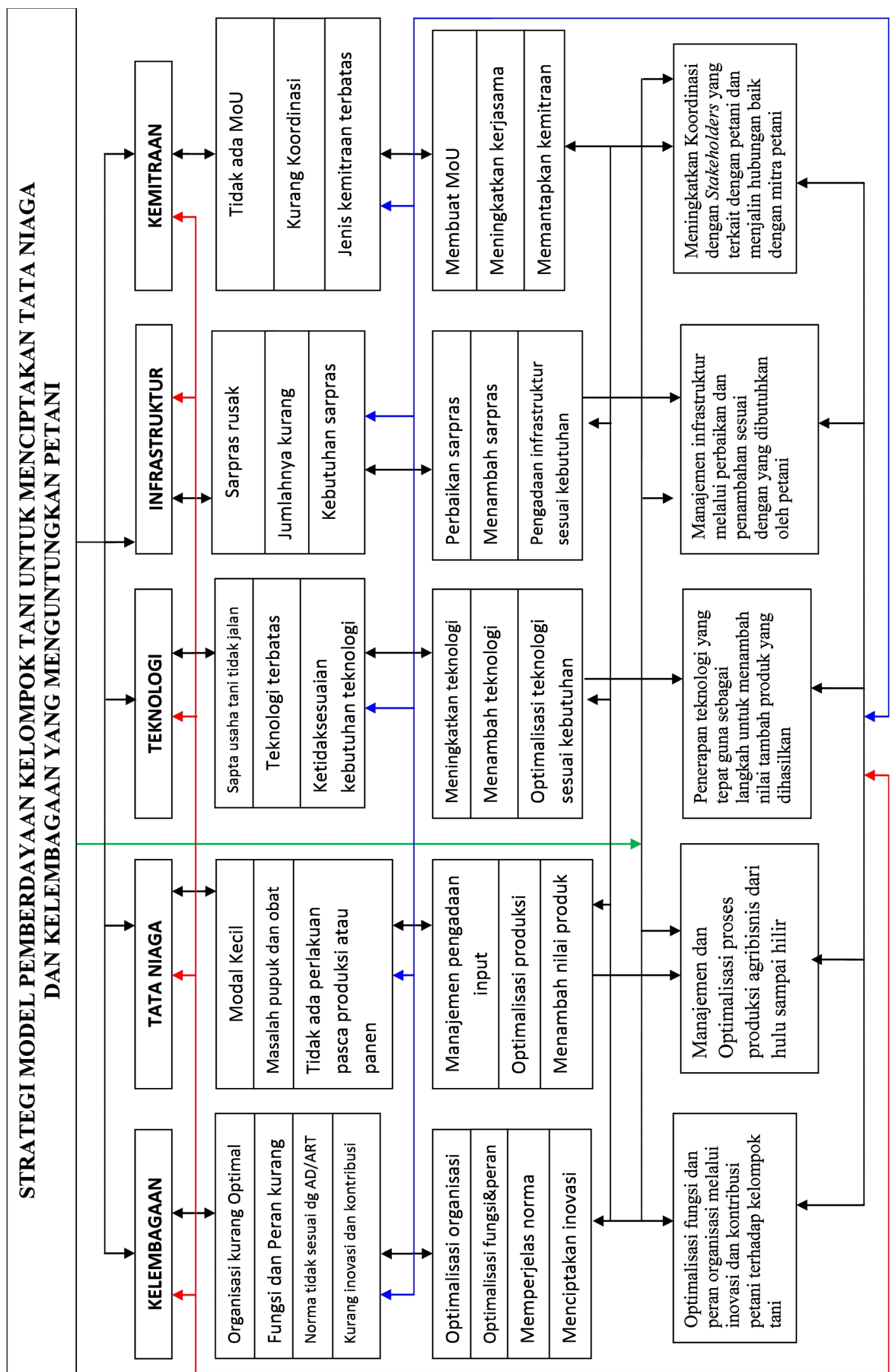

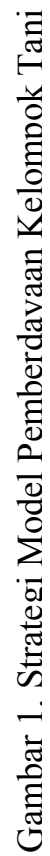


Jurnal Ekonomi Pembangunan, 16 (1), Juni 2015, 33-45

\subsection{Hasil ANP}

\subsubsection{Pairwise comparison dan Rater Agreement.}

Data yang diperoleh dari pengisian kuesioner selanjutnya diolah menggunakan software $\mathrm{Su}$ per Decision 2.0.8 dan Microsoft Excel 2007. Berdasarkan Wawancara dan pengisian kuesioner menghasilkan beberapa temuan yaitu prioritas permasalahan, prioritas solusi dan prioritas strategi. Penjelasan lebih rinci dari temuan yang diperoleh adalah sebagai berikut:

1) Prioritas Aspek. Aspek dalam penguatan kelembagaan kelompok tani terdiri dari 5 aspek yaitu aspek kelembagaan, tata niaga, teknologi, infrastruktur dan kemitraan. Berdasarkan hasil perhitungan ANP, maka diperoleh aspek yang menjadi prioritas yaitu aspek kelembagaan.

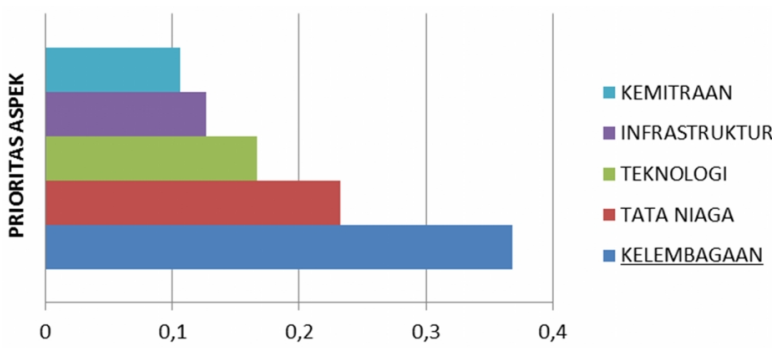

Sumber: data diolah

Gambar 2. Prioritas Aspek

2) Prioritas Masalah. Permasalahan dalam penguatan kelembagaan kelompok tani terbagi berdasarkan aspek yang telah diidentifikasi yaitu permasalahan kelembagaan, tata niaga, teknologi, infrastruktur, dan kemitraan. Berdasarkan hasil perhitungan ANP, maka diperoleh permasalahan yang menjadi prioritas berdasarkan masing-masing aspek.

a) Permasalahan aspek kelembagaan. Permasalahan aspek ini terdiri dari 4 permasalahan yaitu organisasi yang kurang optimal, fungsi dan peran yang kurang dirasakan petani, norma yang tidak sesuai dengan AD/ ART serta kurangnya inovasi dan kontibusi dari dan bagi petani. Berdasarkan perhitungan ANP, prioritas permasalahan aspek kelembagaan adalah norma yang tidak sesuai dengan AD/ART.

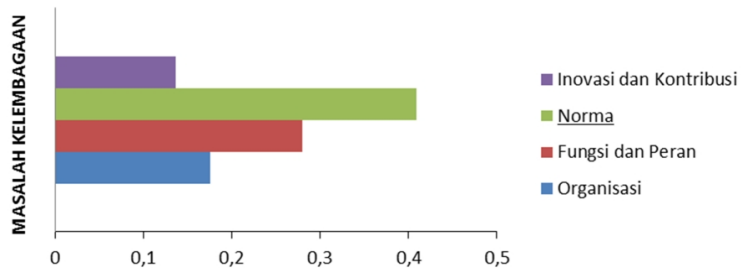

Sumber: data diolah

Gambar 3. Prioritas permasalahan kelembagaan

b) Permasalahan aspek tata niaga. Ada 3 permasalahan dalam aspek tata niaga ini antara lain yaitu modal petani yang kecil sehingga tidak memenuhi input yang dibutuhkan, masalah pengadaan pupuk dan obat hama dalam proses produksi pertanian, tidak ada perlakuan menambah nilai produk yang dihasilkan pascapanen. Berdasarkan hasil ANP, yang menjadi prioritas permasalahan tata niaga adalah masalah pengadaan pupuk dan obat hama dalam proses produksi.

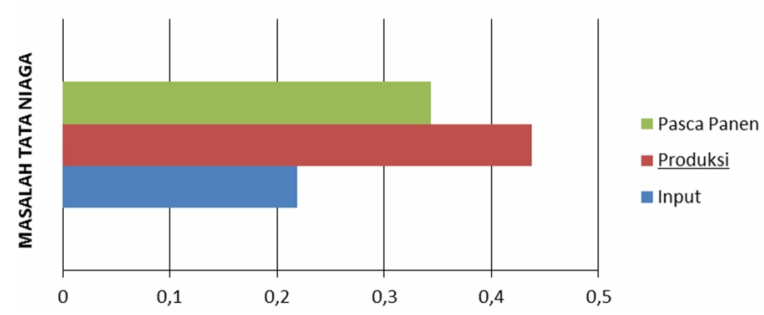

Sumber: data diolah

Gambar 4. Prioritas permasalahan tata niaga

c) Permasalahan aspek teknologi. Permasalahan dalam teknologi antara lain meliputi kurang optimalnya dalam penerapan teknologi, jenis dan jumlahnya terbatas, serta ketidaksesuaian teknologi. Berdasarkan hasil ANP, permasalahan teknologi yang menjadi prioritas yaitu kurang optimalnya dalam penerapan teknologi (standar mutu), khususnya dalam sapta usaha tani. 
Jurnal Ekonomi Pembangunan, 16 (1), Juni 2015, 33-45

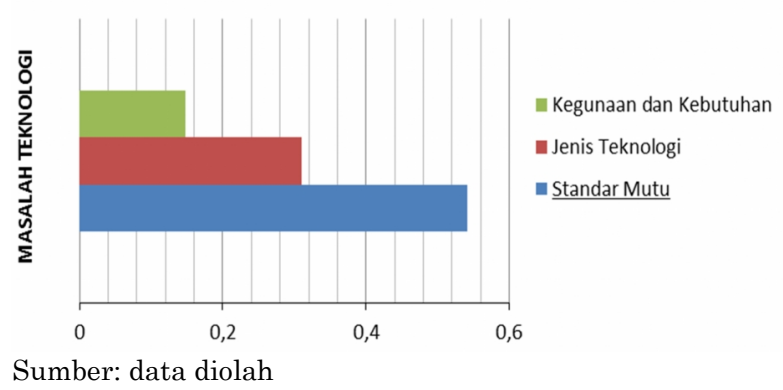

Gambar 5. Prioritas permasalahan teknologi

d) Permasalahan aspek infrastruktur. Aspek infrastruktur mempunyai beberapa masalah yaitu masalah sarpras yang rusak, jumlah sarpras yang masih kurang, dan kebutuhan sarpras yang masih banyak. Berdasarkan hasil ANP, maka diperoleh prioritas masalah infrastruktur yaitu jumlah sarpras yang masih kurang dalam mendukung kegiatan atau usaha pertanian.

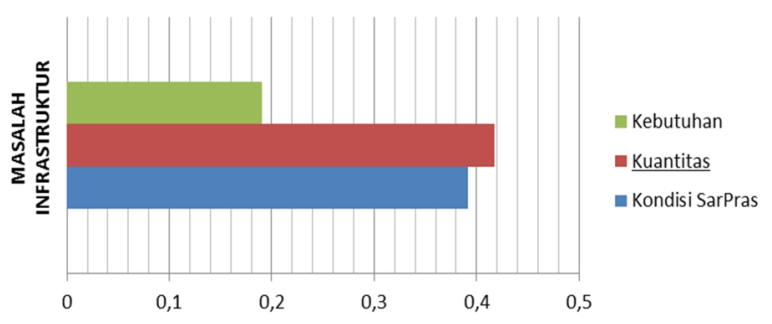

Sumber: data diolah

Gambar 6. Prioritas permasalahan infrastruktur

e) Permasalahan aspek kemitraan. Ada tiga permasalahan yang terjadi dalam aspek kemitraan, antara lain yaitu tidak adanya MoU, koordinasi stakeholders yang lemah, jenis kemitraan yang masih terbatas. Berdasarkan hasil ANP, prioritas permasalahan kemitraan yaitu koordinasi antar stakeholders yang masih lemah dan kurang intensitasnya.

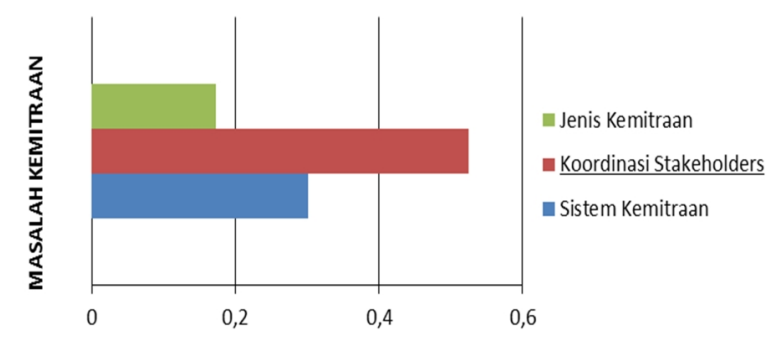

Sumber: data diolah

Gambar 7. Prioritas permasalahan kemitraan

\section{3) Prioritas Solusi}

a) Prioritas solusi kelembagaan. Solusi aspek kelembagaan antara lain yaitu optimalisasi organisasi, optimalisasi peran dan fungsi peran, memperjelas norma, serta memperbanyak inovasi dan kontribusi. Berdasarkan hasil ANP, prioritas solusi aspek kelembagaan yaitu optimalisasi fungsi dan peran sesuai AD/ART.

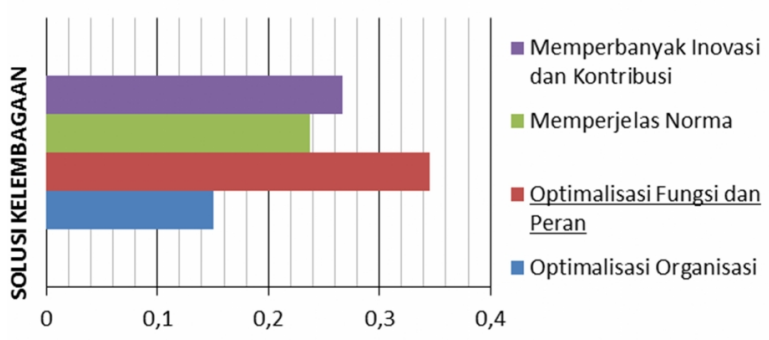

Sumber: data diolah

Gambar 8. Prioritas solusi kelembagaan

b) Prioritas solusi tata niaga. Solusi dalam aspek tata niaga antara lain meliputi manajemen input, optimalisasi produksi dan perlakuan hasil produksi serta pemasaran pascapanen sesuai konsumen. Hasil ANP menunjukkan manajemen pengadaan input menjadi solusi tata niaga yang diprioritaskan.

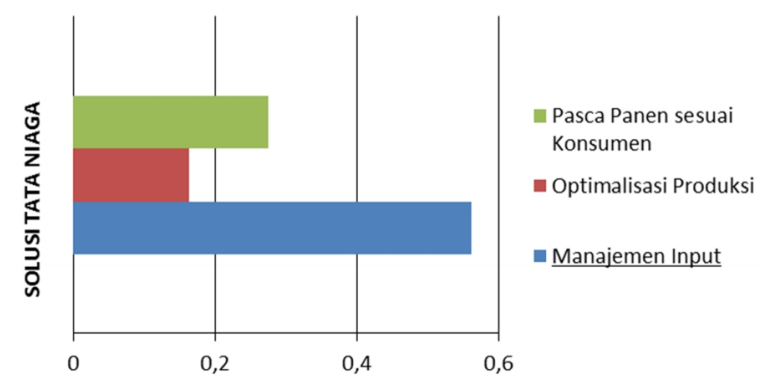

Sumber: data diolah

Gambar 9. Prioritas solusi tata niaga

\section{c) Prioritas solusi teknologi}

Solusi dalam aspek teknologi antara lain yaitu meningkatkan teknologi, menambah jenis dan jumlah, serta optimalisasi teknologi. Berdasarkan hasil ANP, maka diperoleh hasil prioritas dari solusi teknologi adalah meningkatkan teknologi guna meningkatkan mutu produk yang akan dihasilkan oleh petani. 
Jurnal Ekonomi Pembangunan, 16 (1), Juni 2015, 33-45

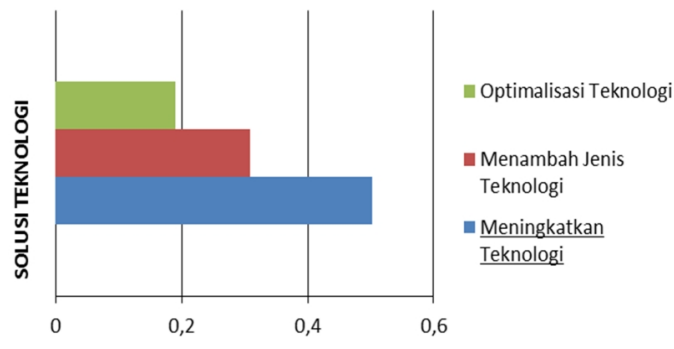

Sumber: data diolah

Gambar 10. Prioritas solusi teknologi

d) Prioritas solusi infrastruktur. Solusi dalam aspek infrastruktur terdiri dari perbaikan sarpras, penambahan sarpras dan pengadaan infrastruktur sesuai kebutuhan petani. Berdasarkan hasil ANP, maka prioritas solusi aspek infrastruktur yaitu perbaikan sarana dan prasarana yang rusak dan tidak layak.

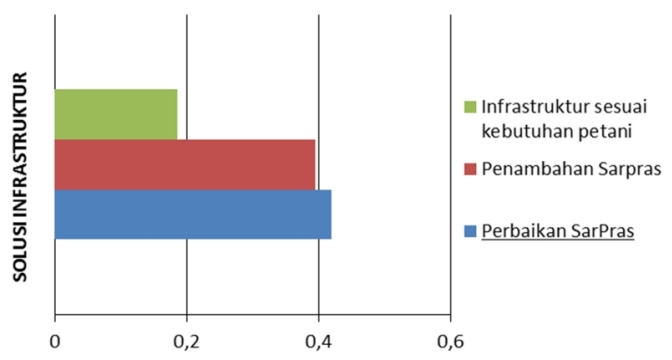

Sumber: data diolah

Gambar 11. Prioritas solusi infrastruktur

\section{e) Prioritas solusi kemitraan}

Solusi dalam aspek kemitraan yaitu antara lain meliputi membuat MoU, meningkatkan kerjasama, dan memantapkan kemitraan yang sudah ada. Berdasarkan hasil ANP, maka yang menjadi solusi kemitraan yang diprioritaskan yaitu memantapkan kemitraan yang sudah ada yang meliputi pasar, teknologi dan permodalan.

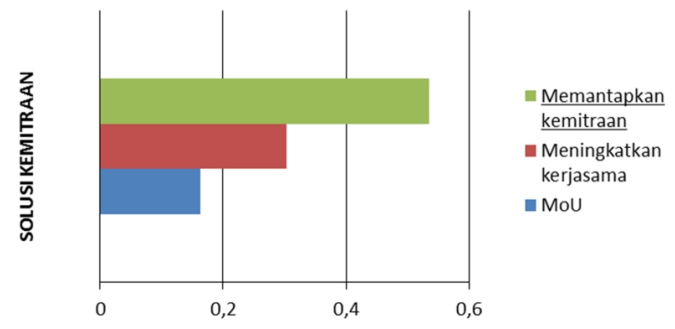

Sumber: data diolah

Gambar 12. Prioritas solusi kemitraan

\section{f) Prioritas Strategi}

Berdasarkan hasil identifikasi dan analisis pada permasalahan serta solusi masing-masing aspek dalam penguatan kelembagaan kelompok tani di Kabupaten Demak, maka diperoleh beberapa alternatif strategi yang ditawarkan yaitu meliputi optimalisasi fungsi dan peran organisasi, manajemen dan optimalisasi proses agribisnis, penerapan teknologi yang tepat guna, manajemen infrastruktur melalui perbaikan dan penambahan, serta meningkatkan koordinasi dengan stakeholders. Berdasarkan hasil ANP, maka diperoleh prioritas alternatif strategi yang digunakan untuk memecahkan permasalah yang ada yaitu penerapan teknologi yang tepat guna sebagai langkah untuk menambah nilai tambah produk yang dihasilkan oleh petani.

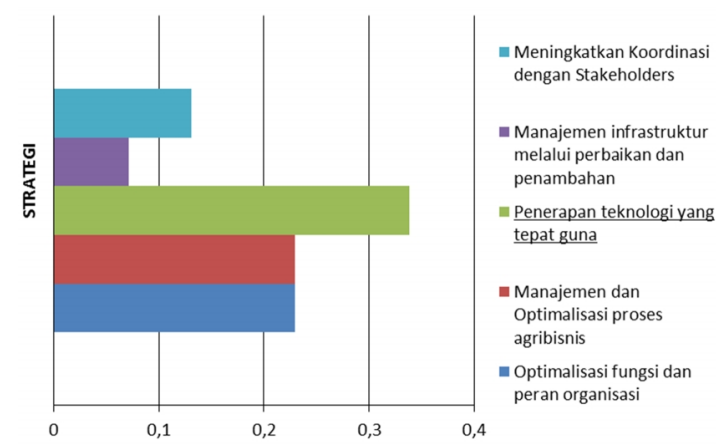

Sumber: data diolah

Gambar 12. Prioritas Strategi

\section{Simpulan}

Studi ini menghasilkan beberapa kesimpulan antara lain sebagai berikut:

(1) Aspek yang menjadi prioritas dalam penguatan kelembagaan kelompok tani di Kabupaten Demak yaitu aspek kelembagaan.

(2) Prioritas permasalahan dalam penguatan kelembagaan kelompok tani di Kabupaten Demak dibagi berdasarkan aspek. Permasalahan aspek kelembagaan yaitu norma yang tidak sesuai dengan AD/ART. Permasalahan aspek tata niaga adalah masalah pengadaan pupuk dan obat hama. Permasalahan aspek teknologi yaitu kurang optimalnya dalam penerapan teknologi dalam sapta usaha tani. Permasalah- 
an aspek infrastruktur yaitu jumlah sarpras yang masih kurang dalam mendukung kegiatan atau usaha pertanian. Permasalahan aspek kemitraan yaitu koordinasi antar stakeholders yang masih lemah dan kurang intensitasnya.

(3) Prioritas solusi dalam penguatan kelembagaan kelompok tani di Kabupaten Demak juga dibagi berdasarkan aspek. Prioritas solusi kelembagaan yaitu optimalisasi fungsi dan peran sesuai AD/ART. Prioritas solusi tata niaga yaitu manajemen pengadaan input. Prioritas solusi teknologi yaitu meningkatkan teknologi guna meningkatkan mutu produk yang akan dihasilkan oleh petani. Prioritas solusi infrastruktur yaitu perbaikan sarana dan prasarana yang rusak dan tidak layak. Prioritas solusi kemitraan yaitu memantapkan kemitraan yang sudah ada yang meliputi pasar, teknologi dan permodalan.

(4) Strategi yang menjadi prioritas dalam penguatan kelembagaan kelompok tani di Kabupaten Demak yaitu penerapan teknologi yang tepat guna sebagai langkah untuk menambah nilai tambah produk yang dihasilkan oleh petani.

\section{Daftar Pustaka}

Anantanyu, Sapja. 2008. Tipe petani dan strategi pengembangan kelembagaan kelompok petani (Kasus di Provinsi Jawa Tengah). Jurnal M'POWER, No. 8 Vol.8, Oktober 2008.

Anantanyu, Sapja. 2011. Kelembagaan petani: peran dan strategi pengembangan kapasitasnya. Jurnal SEPA, Vol. 7 No. 2 Februari 2011: 102-109.

Arifin, Bustanul. 2004. Analisis ekonomi pertanian Indonesia. Jakarta: Penerbit Buku Kompas.

Ascarya. 2010. Determinan dan persistensi margin perbankan konvensional dan syariah di Indonesia. working paper series No.WP/10/04. Pusat Pendidikan dan Studi Kebanksentralan Bank Indonesia.

Cahyono, Sandy dan Dewi Sawitri T. 2013. Peran kelembagaan petani dalam mendukung keberlanjutan pertanian sebagai basis pengembangan ekonomi lokal. Jurnal Perencanaan Wilayah dan Kota, SPPK, Vol. 2 No. 1.

Hasan, Novri. 2009. Strategi penguatan kelompok tani dalam pengembangan usaha: kasus kelompok tani karya agung desa Giriwinangun, Kecamatan Rimbo Ilir, Kabupaten Tebo Provinsi Jambi. Sekolah Pascasarjana Institut Pertanian Bogor.

Hermanto dan Dewa K.S.S. 2011. Penguatan kelompok tani: langkah awal peningkatan kesejahteraan petani. Jurnal Analisis Kebijakan Pertanian, Vol 9 No. 4, Desembe 2011: 371-290.

Kartasasmita, Ginanjar. 1996. Pembangunan untuk rakyat: memadukan pertumbuhan dan pemerataan. Jakarta. Cides.

Nasrul, Wedi. 2012. Pengembangan Kelembagaan Pertanian untuk Peningkatan Kapasitas Petani terhadap Pembangunan Pertanian. Jurnal Menara Ilmu Vol. III No.29, Juni 2012.

Parma, Putu Gede. 2014. Pengembangan model penguatan lembaga pertanian sebagai prime mover pembangunan kawasan daerah penyangga pembangunan (DPP) Destinasi Wisata Kintamani-Bali. Jurnal Ilmu Sosial dan Humaniora, Vol. 3, No.1, April 2014.

Rangkuti, F. 2006. Analisis swot teknik membedah kasus bisnis, cetakan Keduabelas. Jakarta: PT. Gramedia Pustaka Utama.

Saaty, T. \& Vargas, L. 1993. Models, methods, concepts and applications of the analytic hierarchy process. USA: Springer Science.

Sulistiyani, A.T. 2004. Kemitraan dan modelmodel pemberdayaan. Jogjakarta. Gava Media.

Suradisastra, Kedi. 2008. Strategi pemberdayaan kelembagaan petani. Jurnal Forum Penelitian Agro Ekonomi, Vol. 26 No. 2 Desember 2008.

Wahyuni, Sri. 2003. Kinerja kelompok tani dalam sistem usaha tani padi dan metode pemberdayaannya. Jurnal Litbang Pertanian, 22 (1), 2003. 